\title{
Physics Achievement Test Implies Students' Self-Efficacy on Decision Making Process
}

\author{
Dian Mayasari ${ }^{1}$, Riski Muliyani ${ }^{2}$, Yudi Kurniawan ${ }^{3}$, Iip Istirahayu ${ }^{4}$ \\ College of Teacher Training and Education (STKIP) Singkawang, Singkawang, Indonesia \\ diansingkawang@gmail.com¹, kikiriski1012@gmail.com², yudikurniawan1012@gmail.com³, \\ iip_istirahayu@yahoo.com ${ }^{4}$
}

Received: March $10^{\text {th }}, 2019$. Revised: May $15^{\text {th }}, 2019$. Accepted: May $26^{\text {th }}, 2019$

\section{Keywords :}

Physics Achievement Test; Self-Efficacy; Decision Making

\begin{abstract}
This research was conducted to provide a comprehensive description about how the results of the cognitive learning outcomes of the physics field were indirectly supported by self-efficacy in the decision making process of the beliefs of the chosen answers. This research is descriptive qualitative research and involves 24 samples of class $X$ students. The sample technique chosen was purposive sampling. The testing of cognitive learning outcomes in cognitive domains was conducted and designed by physics education lecturers and self-efficacy testing carried out and designed by lecturers in the direction of guidance and counseling using attitude scales. This combination of measurements produces two decisions on self-efficacy: positive and negative. The results of the study showed that students with high self-efficacy got high scores also on the physics test of cognitive learning outcomes. These students are classified as students with positive self-efficacy. Conversely, negative self-efficacy shows that students have high self-efficacy but get low cognitive test results in cognitive domains. These results are certainly influenced by several factors including uncertainty and anxiety.
\end{abstract}

\section{INTRODUCTION}

Nowadays, the implementation of Kurikulum 2013 in almost all of school in Indonesia, shown that the characterize of learning process must be scientific approaches and integrated and refers to the discovery learning process (Regulations of Ministry of Education and Culture of the Republic of Indonesia, 2016) [1]. Therefore, the teaching-learning process that occurs in the classroom determines the extent to which learning achievements may be obtained [2] found that the student-centered learning process is believed to have a positive impact on his cognitive abilities because it involves students to do it themselves, analyze themselves and draw their own conclusions. With such learning experience, students will tend to be more confident in themselves and have an impact on the increased learning outcomes of the cognitive domain. This process had similarity with psychology terms, called as: self-efficacy. Etymologically, self-efficacy contains two words that are "self" and "efficacy". Self 
is defined as the element or structure of personality, while efficacy is self-assessment of the ability to perform actions that are considered good or considered bad, remain wrong, can or cannot do as required [3].

Self-efficacy is the power of someone's belief in their ability to accomplish a task or achieve goals [4]. Someone's self-efficacy affects to every area of human endeavor. Bandura defines self-efficacy as human's beliefs about their ability to succeed in specific situations [5]. Bandura [6] adds that personal beliefs affect action, effort, perseverance, joy over differences, and concrete realities of goals. Selfefficacy was concerned with the consideration that individuals make about their ability to perform behaviors appropriate to a particular task or situations. They able to organize and perform an action necessary to manage a prospective situation. In other words, self-efficacy is someone's belief in someone's ability to succeed in certain situations. This belief as a determinant of how people think, behave and feel [6].

Based on the above description, self-efficacy in principle leads to self-confidence. In this study, selfefficacy that measured based on the three aspects. These aspects 1): Level, the degree of task difficulties level. Its means that judgement by student to able to complete the task; 2) Generality, range of attitude. This aspect measured by special situation that they can handle it nicely because they confident about himself; 3) Strength, the strongest confidence about himself based on his own ability [7]. Self-efficacy refers to the strength of individual self-confidence to be able to perform a task or activity affecting motivation, and achievement. Learning process that provides learning experience also allegedly can provide students confidence in solving problems at school or in everyday life. Students with high self-efficacy have greater endurance and enthusiasm in the learning process than the low ones so that students with high self-efficacy tend to be more confident [2]. In fact, especially in the field of physics learning, the low self-esteem of students is also the impact of the lack of skills / experience in learning [8]. Therefore, it can be expected that students who believe in knowledge (both cognitive and psychomotor cognition) will be better able to achieve optimal learning outcomes. Based on those of literatures, it can conclude that self-efficacy was related to cognitive domain learning outcomes. In the realm of physics, the learning outcomes of the cognitive domain is the ultimate goal of the learning process in the classroom. Based on the background, the research question is how the implication of self-efficacy on the physics achievement mark?

\section{METHOD}

This research is a qualitative descriptive study. This research was conducted at one SMA Negeri in Singkawang City as many as 24 students. The sampling has taken by purposive sampling technique. This technique used with main consideration that if student not yet completely learn the subject matter tested in this study, it could definitely that student unsure about their answers. Instruments used are physics achievement test (PAT) and attitudes scales (AS). The PAT was constructed by physics lecturers and AS was construct by guided and counselling lecturers. The concept of physics in the PAT was dynamic electrical concept.

PAT's structure was multiple choice items. This item consists two part; Part-1 was tested about conceptual physics understanding and $2^{\text {nd }}$ part was asked students' confidences in the answering test. The process of filling PAT (by students) is designed in two stages. Phase I is a general question; Phase II is a question of argument / idea. These stages are set up to help the researcher clearly illustrate how to determine students who actually have good self-efficacy or just do physics. After that, student filled AS that provided prior test.

In this study, analysis of the results of the students' self-efficacy are divided into two types: selfefficacy positive and self-efficacy negative. Positive self-efficacy means that students have high selfefficacy so that the impact has a high PAT mark. Conversely, negative self-efficacy indicates that students who have high self-efficacy but low PAT mark. 


\section{RESULTS AND DISCUSSIONS}

Based on the study was held, the result of this study would separate into two segments. The first one was on the physicist paradigm and the last one based on psychology aspect which analyzed by guided and counseling paradigm. As state as on the method, this result has analyzed by two parts: Phase I and Phase II. Generally, there are two students that their mark on physics test proportional with their selfefficacy. The others (22 students) didn't had self- efficacy on the right goal.

The decision of self-efficacy on physics achievement test are the following:

1. Positive self-efficacy categorizes: two students (8\%): higher mark and higher self-efficacy.

2. Positive self-efficacy categorizes: five students (21\%): lower mark and lower self-efficacy.

3. Negative self-efficacy categorizes: five students (71\%): lower mark but higher self-efficacy.
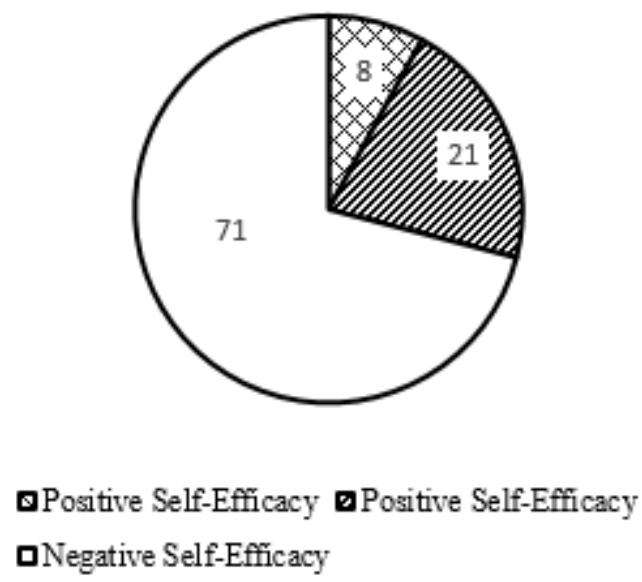

Fig 1. The Percentage of self-efficacy in PAT

Based on the Figure 1,21\% is student with lower PAT and less confidence in the answering test. Some of the number of students' answers on Phase I that being the focal point of study was:

1. Student (code R05) have no confidence in answering the questions given so that no one question is answered correctly.

2. Student (code R13) have confidence in answering the questions given but all the answers he believes are wrong.

3. Student (code R03) have good confidence but the result of the answer is analyzed as a guess (lucky guess).

4. Students with (code R09 and R11) have good confidence so that the they answered almost perfect confidently.

The results are deepened by the researchers to provides a comprehensive overview of how students' beliefs in answering the questions are given by their teachers. The researcher questioned the students' arguments on the outcome of the original question.

Based on the results of the argumentation analysis (Phase II) then obtained some significant findings as follows.

1. Student (code R05) was unable to provide arguments with confidence so as to reinforce the results of the previous analysis.

2. Students (codes R22 and R24) were the students with the highest quantity in which they were unable to provide the correct argument with conviction so that this data becomes a finding that complements the results of the previous stage analysis. 
3. Students (code R09 and R11) have good confidence in defending their arguments so that argument analysis supports the results of the previous stage analysis.

The finding of students (code R22 and R24) that they were unable to provide arguments with selfbelief, it can be reviewed backward to the previous stage that the two students were not able to answer the questions correctly and confidently in Phase I, and finally discovered / illustrated the results clearly after clarify the argumentation on Phase 2.

In the case of student 13 (code R13) it was found that the student's self-efficacy was negative. That student feels confident in answered test but the answer was he/she believed to be the wrong answer. The mistake in understanding the information / data presented (in this study is the explicit information or clues) in the matter ultimately will result in the conclusion that not mastery concept [8]. Further that, if this mistake exists in the beginning of the class, it must be replacing with the correct one after class ended [9].

Another finding (code R05), it was found that the value of self-efficacy was positive. However, this result is poor if it is associated with general learning objectives. This result can be read as this student does not believe in his ability and he does not master the concept. This is a problem that must be solved immediately because the desired outcome in the learning process is not achieved. This problem can only be solved through treatment / intervention in the learning process (which is not a subject of this study). Mastery concept is allegedly closely related to the learning model used by the teacher whether it is informative or constructive so as not to ignore the knowledge that has been owned by students [10].

In the student (code R3), the results of the analysis show that the self-efficacy of R03 students was positive. This case was almost the case with R05, the differences of them were R05 students believe the wrong answer while the R03 students do not believe the correct answer. It also does not have a good impact. Although the results of the analysis found a number of correct answers, but the correct answer was chosen with no confidence.

The ideal learning objectives should produce data as such as students R9 and R11 where there was a cognitive consistency cognitive, consistency confidence starting from Phase I to Phase II completion of PAT. Based on the brief exposure can be said in general, there is a link between students' selfconfidence with the chosen answer.

As complimentary the findings of study, as the following there are states four factors that could be made up the self-efficacy: performance experience, other people's experiences, social persuasion, and emotional state [3]:

\section{Performance Experience}

Success and achievement leads to increased self-efficacy. Performance experience is an achievement he has achieved in the past. Past performance has been the most powerful confidence-boosting factor.

Success will impact on self-efficacy that varies depending on the process of achievement. (a) A person who is successful, failing occasionally does not affect his or her own efficacy; (b) the more difficult the task is, the success it achieves will make its self-efficacy even higher; (c) Self-employment (independently) will improve self-efficacy compared to the work of others and group work; (d) failure under stressful conditions is not as bad as when conditions are optimal; (e) Failure in people who already have strong self-efficacy is not as bad as those whose self-efficacy beliefs have not been strong.

\section{Other People's Experiences}

Through other social models the experience of others can be obtained, so that self-efficacy can increase as individuals observe others of equal ability. It implies that the other person is different from the individual, then the impact of the experience of others will have an insignificant self-efficacy effect for him. Generally, it can be said that personal performance enhances a higher self-efficacy 
compared to the impact caused by the experience of others. However, other people's experiences have a strong influence when they show a decrease in self-efficacy [3].

\section{Social Persuasion}

Feits, et.al [3] states social persuasion can strengthen or weaken one's self-efficacy. The influence of social persuasion sources was limited, but under accurate and appropriate conditions persuasion from others can increase or decrease the level of self-efficacy. A strong sense of confidence in persuasion demonstrates the right conditions to improve self-efficacy.

\section{Emotional Conditions}

Changes in behavior can occur when the source of self-efficacy expectations change. The state of emotion that follows the activity of a field influences one's self-efficacy in the field. It may be that one's self-efficacy diminishes when there is strong emotion, fear, anxiety, or stress. Changes in selfefficacy are used to correct the difficulty and adaptation of the behavior of people with behavioral problems. According to Trans Theoretical Model [11], self-efficacy and the results of positive understanding ("pros") and negative understanding ("cons") are seen as cognitive social variables that change over time. Self-efficacy especially low will increase as individuals move to higher levels. Selfefficacy is synonymous with the students' self-belief in performing and executing the task of accomplishing tasks and achieving certain goals in digesting and studying physics.

Self-efficacy is a person's belief in their abilities and has been shown to affect student physics achievements [12]. Bandura et al. [13] argues that self-efficacy can affect many parts of a person's life such as "the level of motivation and perseverance in the face of adversity and decline, resistance to adversity, the quality of analytical thinking." From that opinion, it is clear that self-efficacy is required in the study of physics. This step could be difficult but not impossible so the important things is teachers should create a condition where their student have the motivation, perseverance, and resilience to continue to show effort in the physics classes.

\section{CONCLUSION AND SUGGESTION}

The result of comprehensive discussions, it can conclude that self-efficacy could imply the students' mark on the physics achievement test. This implication could have described in some categorizes that positive self-efficacy categorizes: two students $(8 \%)$ "higher mark and higher self-efficacy, positive self-efficacy categorizes: five students $(21 \%)$ "lower mark and lower self-efficacy, and negative selfefficacy categorizes: five students (71\%) "lower mark but higher self-efficacy.

\section{REFERENCES}

[1] Peraturan Menteri Pendidikan dan Kebudayaan RI Nomor 22 Tahun 2016 Tentang Standar Proses Pendidikan Dasar dan Menengah.

[2] Hamzah, A. R., Achmad, Z., \& Shohib, M. (2014). Efektivitas Pelatihan Sefy Untuk Meningkatkan Efikasi Diri Dalam Pengambilan Keputusan Karir Siswa. Jurnal Intervensi Psikologi, 6(1): 103-116.

[3] Alwisol. (2009). Psikologi Kepribadian (edisirevisi). Malang: UMM Press.

[4] Ormrod, J. E. (2006). Educational Psychology: Developing Learners (5th Edition). Ohio: Pearson.

[5] Luszczynska, A., Mohamed, N. E., \& Schwarzer, R. (2005). Self-efficacy and social support predict benefit finding 12 months after cancer surgery: The mediating role of coping strategies. Psychology, Health \& Medicine, 10(4): 365-375.

[6] Bandura, A. (1994). Self-efficacy. In V. S. Ramachaudran (Ed.), Encyclopedia of human behavior, 4: 71-81. New York: Academic Press. (Reprinted in H. Friedman [Ed.], Encyclopedia of mental health.) San Diego: Academic Press. 
[7] Yuliantika, D., Rahmawati, S. W., \& Palupi, S. R. (2017). Self- Efficacy dan Motivasi Berprestasi Siswa SMA Negeri 7 Purworejo. Jurnal Psiko Utama, 5(2): 51-59.

[8] Muliyani, R., Kurniawan, Y., \& Sandra, D. A. (2017). Peningkatan Keterampilan Proses Sains Terpadu Siswa melalui Implementasi Levels of Inquiry (LoI). Tadris: Jurnal Keguruan dan Ilmu Tarbiyah, 2(2): 81-86.

[9] Kurniawan, Y., Suhandi, A., \&Hasanah, L. (2016). The influence of implementation of interactive lecture demonstrations (ILD) conceptual change oriented toward the decreasing of the quantity students that misconception on the Newton's first law. In AIP Conference Proceedings, 1708 (1): 070007.

[10] Kurniawan, Y. (2018). Investigasi level miskonsepsi pada Hukum III Newton. Jurnal Riset dan Kajian Pendidikan Fisika, 5(1): 17-21.

[11] Prochaksa, J.O., \& DiClemente, C.C. (1992). The transtheoretical approach. In J. Norcross \& M. Goldfried(Eds.), Handbook of Psychotherapy Integration. New York: Brunner.

[12] Pajares, F., \& Miller, M. D. (1995). Mathematics self-efficacy and mathematics outcomes: The need for specificity of assessment. Journal of Counseling Psychology, 42: 190-198.

[13] Bandura, A., Barbaranelli, C., Caprara, G. V., \& Pastorelli, C. (1996). Multifaceted impact of self-efficacy beliefs on academic functioning. Child development, 67(3): 1206-1222. 